\title{
Reef Crest
}

\section{Reef Slope}

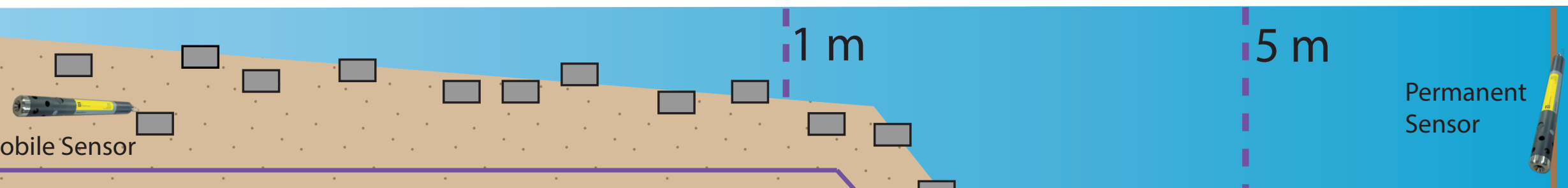

24 meters 